\title{
LEADERIA:
}

JURNAL MANAJEMEN PENDIDIKAN ISLAM

Volume 2, Nomor 2, Desember 2021, Hal. 62-70

\section{MANAJEMEN RISIKO DI MI MUHAMMADIYAH KENTENG}

\author{
Farid Setiawan ${ }^{1}$, Cevina Rinda Ardita ${ }^{2}$, Alinda Syarofah ${ }^{3}$, Muhammad Zaki ${ }^{4}$ \\ ${ }^{1}$ Universitas Ahmad Dahlan, Jalan Wates - Purworejo,Wates, Daerah Istimewa Yogyakarta, Indonesia \\ e-mail: farid.setiawan@pai.uad.ac.id \\ ${ }^{2}$ Universitas Ahmad Dahlan, Jalan Wates - Purworejo,Wates, Daerah Istimewa Yogyakarta, Indonesia \\ e-mail: cevina1900331006@webmail.uad.ac.id \\ ${ }^{3}$ Universitas Ahmad Dahlan, Jalan Wates - Purworejo,Wates, Daerah Istimewa Yogyakarta, Indonesia \\ e-mail: alinda1900331007@webmail.uad.ac.id \\ ${ }^{4}$ Universitas Ahmad Dahlan, Jalan Wates - Purworejo,Wates, Daerah Istimewa Yogyakarta, Indonesia \\ e-mail: $\underline{\text { muhammad1900331051@webmail.uad.ac.id }}$
}

\begin{abstract}
In the world of education, of course, there are several factors that can affect the development of an educational institution, one of which is risk. The existence of a risk can certainly have a negative impact on the development of an educational institution. However, this risk cannot be simply avoided, the risk can be managed or controlled, so that it does not have such a big impact. Therefore, an institution requires a management or what is known as risk management, which is used to identify, measure, control and evaluate the risks created by the implementation of educational programs. So in this study the aim is to find out how to implement risk management in the education program at SD MI Muhammadiyah Kenteng. The method used is a qualitative method where in obtaining data interviews with the school then the results of the interviews are discussed together so that a conclusion is obtained that the risks found at MI Muhammadiyah Kenteng consist of internal risks and external risks, where the internal factors found are infrastructure that the condition is not good, the teaching staff between non-permanent teachers and civil servants is not balanced, then from external factors such as the stigma of the community who are not too familiar with or understand the name of Madrasah. At the stages of risk management at MI Muhammadiyah Kenteng include identifying problems where identification by analyzing and monitoring the presence of internal and external factors, measuring risk is done through student growth diagrams, by looking at the data can apply what actions need to be taken to overcome risks (lack of participants). students), controlling risk by selecting options that can reduce negative risks arising or transferring risks that will arise and finally evaluating risk is carried out in various ways such as discussions, meetings and so on, in which it is discussed how ways or steps can be taken. of the risks that have been identified in the previous stages.
\end{abstract}

Keywords: management, risk, education 


\begin{abstract}
ABSTRAK
Dalam dunia pendidikan tentu terdapat beberapa faktor yang dapat mempengaruhi perkembangan sebuah lembaga pendidikan, salah satunya adalah risiko. Adanya sebuah risiko tentu dapat memberikan dampak negatif bagi perkembangan suatu lembaga pendidikan. Namun risiko ini tidak dapat dihindari begitu saja, risiko dapat dikelola atau dikendalikan, sehingga tidak berdampak begitu besar. Oleh karena itu dalam suatu lembaga dibutuhkan suatu pengelolaan atau yang disebut dengan manajemen risiko, yang digunakan untuk mengidentifikasi, mengukur, mengendalikan dan mengevaluasi risiko yang tercipta dari pelaksanaan program pendidikan. Sehingga pada penelitian kali ini bertujuan untuk mengetahui bagaimana pengimplementasian manajemon risiko dalam program pendidikan di SD MI Muhammadiyah Kenteng. Metode yang digunakan adalah metode kualitatif dimana dalam memperoleh data dilakukan interview dengan pihak sekolah kemudian hasil dari interview tersebut didiskusikan bersama sehingga diperoleh suatu kesimpulan bahwa risiko yang ditemukan di MI Muhammadiyah Kenteng terdiri dari risiko internal dan risiko eksternal, dimana faktor internal yang ditemukan ialah sarpras yang kurang baik kondisinya, tenaga pendidik antar GTT dan PNS kurang seimbang, kemudian dari faktor eksternal seperti stigma masyarakat yang belum terlalu familiar atau paham dengan nama penyebutan Madrasah. Pada tahapannya manajemen risiko di MI Muhammadiyah Kenteng diantaranya adalah mengidentifikasi masalah dimana pengidentifikasian dengan menganalisis dan memantau adanya faktor internal dan eksternal, mengukur risiko dilakukan melalui diagram pertumbuhan peserta didik, dengan melihat data tersebut dapat menerapkan tindakan apa yang perlu dilakukan untuk mengatasi risiko (kekurangan peserta didik), mengendalikan risiko dengan menyeleksi pilihan-pilihan yang dapat mengurangi risiko negatif timbul atau memindahkan risiko yang akan muncul dan yang terakhir adalah mengevaluasi risiko dilakukan dengan berbagai jalan seperti diskusi, rapat dan sebagainya, yang mana didalamnya didiskusikan bagimana cara atau langkah yang dapat diambil dari risiko-risiko yang sudah teridentifikasi pada tahapan-tahapan sebelumnya.
\end{abstract}

KataKunci: manajemen, risiko, pendidikan

\title{
PENDAHULUAN
}

Pendidikan menurut Kamus Besar Bahasa Indonesia merupakan, sebuah usaha mengubah perilaku individual atau kelompok sebagai langkah mendewasakan insan melalui pendekatan pengajaran dan pelatihan. Dalam pelaksanaan pendidikan dibagi menjadi 3 jalur yakni (1) Pendidikan non-formal, (2) Pendidikan informal dan (3) pendidikan formal. Pertama, pendidikan non-formal sebuah aktivitas yang tertata dan sistematis yang dilakukan di luar sistem pendidikan formal. Kedua , Pendidikan informal merupakan sebuah pembelajaran yang berjalan sepanjang hidup oleh tiap insan, hasil pembelajaran ini lebih bersifat pada pengelaman yang didaptkan dari kehidupan sehari hari seperti perilaku, sikap. Ketiga pendidikan formal adalah sebuah pembelajaran yang tersusun, tertata secara sistematis baik yang sifatnya umum maupun khusus, secara berjenjang mulai dari pendidikan dasar kemudian dilanjutkan ke jenjang selanjutnya hingga perguruan tinggi. Salah satu satuan. pendidikan formal adalah madrasah. 
Layaknya sebuah perusahaan, madrasah juga memiliki manajemen, manajemen yang diterapkan madrasah yakni manajemen atau pengolahan, penataan secara terstruktur yang dapat mengembangkan madrasah lebih baik lagi serta memakai tujuan madrasah secara efektif dan efisien. Dalam manajemen kita juga harus mengenal adanya risiko, risiko merupakan hal yang tidak dapat dihindari dalam seluruh kehidupan manusia. Suatu tindakan pasti terdapat risiko yang harus ditanggung oleh pelakunya. Begitupula dalam dunia pendidikan, yang mana memuat banyak aspek yang dapat mendukung dan juga menghambat terlaksananya pendidikan tersebut. (Subagyo, Simanjutak, \& Irianto, 2020). Sehingga dalam pencegahan atau meminimalisir adanya risiko dalam pendidikan, diperlukan pengatur atau manajemen didalamnya. Manajemen sendiri merupakan sebuah proses baik itu perencanaan, pengorganisasian, penggerakan, pengawasan yang mana dimaksudkan untuk mencapai tujuan melalui SDM dan sumberdaya laimya. (Winoto, 2020). Sehingga manajemen risiko merupakan pengimplementasian dari fungsi manajemen sebagai upaya pencegahan adanya risiko, terlebih pada risiko dalam organisasi atau perusahaan, keluarga maupun masyarakat. Yang mana terdiri dari kegiatan merencana, mengorganisir, menyusun, memimpin atau mengkoordinir dan mengawasi (termasuk mengevaluasi) dalam program pecegahan adanya risiko. (Subagyo, Simanjutak, \& Irianto, 2020).

Terdapat beberapa kajian terdahulu yang relevan terhadap penelitian ini. Yakni penelitian oleh Zahrotul Munawwaroh (2017) mengkaji terkait Analisis Manajemen Risiko Pada Pelaksanaan Program Pendidikan Dalam Upaya Meningkatkan Mutu Pendidikan. Perbedaan penelitian terdahulu dengan penelitian ini terletak terdapat pada lokasi penelitian serta apa yang menjadi konteks yang diteliti. Dalam penelitian ini, fokusnya tentang manajemen risiko yang dilakukan di MI Muhammadiyah Kenteng, serta mengkaji terkait tahapan-tahapan yang dilakukan sekolah.

Dalam lembaga pendidikan tak berbeda jauh dengan instansi lainya, manajemen risiko ini menjadi hal penting. Telah diketahui bersama permasalahan dalam dunia pendidikan membawa dampak negatif, permasalahan - permasalahan tersebut mengenai berbagai hal diantaranya pengelolaan asset dan keuangan, sampai dengan kemerosotan mutu lulusan dari semua jenjang. Hal yang melatarbelakangi penulis memilih MI Muhammadiyah Kenteng dikarenakan lokasi dari sekolah tersebut strategis terletak di antara permukiman masyarakat dan terdapat beberapa faktor manajemen yang menarik itu kami teliti pada penelitian yang kami lakukan.Tujuan pembuatan jurnal ini diharapkan dapat memberikan informasi terutama bagaimana cara mengatasi jika sebuah risiko terjadi dalam lingkungan sekolah. Dan bagimana tahapan dari manajmen risiko dalam lembaga kependidikan. 


\section{METODE}

Penelitian ini merupakan penelitian kualitatif. Penelitian kualitatif ini bertujuan untuk mencermati suatu pengalaman dari subyek yang diteliti. Seperti perilaku, presepsi, motivasi, tindakan, dan lain-lain. Yang mana diteliti secara menyeluruh secara deskriptif pada konteks tertentu yang terjadi secara alami tanpa campur tangan seseorang, dengan memanfaatkan metode ilmiah yang biasa digunakan secara maksimal. (Sidiq \& Choiri, 2019). Pada penelitian kali ini penulis menggunakan metode wawancara. Penulis melakukan wawancara denga salah satu pendidik di MI Muhammadiyah Kenteng yakni dengan Bapak Teguh Cahyana, S.Pd.I. teknikini digunakan untuk menggali informasi lebih mendalam, jelas dan terperinci tentang kondisi yang sebenarnya terjadi. Data yang diperoleh memberikan sebuah gambaran umum serta kondisi objektif mengenai risiko-risiko yang dialami oleh lembaga pendidikan MI Muhammadiyah Kenteng Dari data-data yang diperoleh dari lapangan kemudian kami diskusikan sehingga mendapatkan kesimpulan atau kesapakatan bersama dari masalah yang dianalisis. Dalam penulisan jurnal juga menerapkan metode triangulasi, yakni sebuah metode pengumpulan data untuk menguji kualitas data melalui berbagai metode dan sumber data.

\section{HASIL DAN PEMBAHASAN}

\section{Biografi Sekolah MI Muhammadiyah Kenteng}

MI Muhammadiyah Kenteng merupakan salah satu lembaga pendidikan dibawah naungan Kementerian Agama, yang beralamat di Kenteng, Demangrejo, Sentolo, Kulon Progo, DIY. Kepala sekolah MI Muhmmadiyah Kenteng ini adalah Bapak Rujito S.Pd.I, M.Pd. Sekolah ini memiliki ciri khas sebagai Sekolah berbudaya, hal ini dilatarbelakangi oleh kepala sekolah yang memiliki tujuan untuk memperkenalkan pada masyarakat luas bahwa dalam Islam dan seni dapat saling mendukung satu sama lain terutama dalam bidang pendidikan. Juga sebagai media untuk melestarikan kebudayaan yang tentu sesuai dengan syariat Islam. Alasan kami memilih sekolah ini sebagai objek dalam penelitian kami adalah lokasinya yang strategis dan terdapat beberapa faktor manajemen yang menarik itu kami teliti pada penelitian yang kami lakukan.

\section{Konsep Manajemen Risiko}

Risiko merupakan suatu yang selalu dihubungkan dengan kemungkinan yang merugikan tidak diinginkan dan tidak disangka-sangka. Atau dengan kata lain risiko adalah ketidakpastian atau kemungkinan terjadinya sesuatu, jika terjadi akan berakibat kerugian. (Subagyo, Simanjutak, \& Irianto, 2020). Sedangkan manajemen sendiri didefinisikan sebagai proses merencanakan, mengorganisasikan, memimpin dan mengendalikan tindakan dari anggota sebuah organisasi selain itu juga memanfaatkan seluruh sumberdaya untuk mencapai tujuan dari sebuah organisasi. 
(Winoto, 2020). Dari dua pengertian tersebut manajemen risiko dapat dikatakan sebagai pelaksanaan dari fungsi manajemen yang telah disebutkan sebelumnya dan juga mencegah atau meminimalisir adanya risiko yang dapat dialami oleh suatu instansi, keluarga maupun masyarakat. Langkah-langkah dari manajemen risiko ini berawal dengan mengidentifikasi risiko, kemudian melakukan pengukuran risiko, dilanjut dengan pengendalian risiko dan yang terakhir adalah evaluasi risko yang diteridentifikasi dalam instansi tersebut.

Dari hasil wawancara yang dilakukan dapat disimpulkan bahwa manajemen risiko merupakan suatu hal yang penting untuk berjalannya suatu lembaga pendidikan dimana saat ini terjadi peningkatan kepadatan aktivitas dalam lembaga pendidikan yang mana akan menimbulkan peningkatan risiko bagi lembaga pendidikan. Tujuan utama dari pengimplementasian manajemen risiko ini adalah mengantisipasi atau melindungi lembaga pendidikan dari kerugian yang akan ditimbulkan pada sistem implementasi program pendidikan. Dalam pelakasanaan manajemen risiko ini dilakukan dengan menyeimbangkan antara pengelolaan manajemen dan pelaksanaan pendidikan, dengan pengelolaan risiko sehingga pada akhirnya lembaga pendidikan dapat memperoleh hasil yang optimal dari pelaksanaan pendidikan.

\section{Risiko Yang Teridentifikasi Di MI Muhammadiyah Kenteng}

Risiko berdasarkan sumbernya dikelompokan menjadi dua yakni risiko internal dan risiko eksternal. Risiko internal ini merupakan risiko yang bersumber dari dalam instansi itu sendiri,misal kecacatan atau kerusakan akibat kelalain anggota, kecelakaan kerja, keterbatasan fasilitas dan sebagainya. Kemudian risiko eksternal adalah risiko yang bersumber dari luar instansi, seperti risiko pencurian, persaingan, fluktuasi harga, perubahan kebijakan dari pemerintah dan sebagainya. (Winoto, 2020)

Pada proses pengidentifikasian risiko hal pertama yang harus dilakukan adalah dengan menganalisis dan memantau adanya faktor internal dan eksternal. Sehingga ditetapankannya risiko ini kemudian dapat menghasilkan suatu proses alternatif risiko untuk penanganan atau meminimalisir terjadinya risiko tersebut. (Munawwaroh, 2017). Dari hasil wawancara risiko yang dialami oleh MI Muhammadiyah Kenteng ini beragam, dari faktor internal seperti : a) sarpras yang kurang baik kondisinya, b) tenaga pendidik antar GTT dan PNS kurang seimbang, kemudian dari faktor eksternal seperti: a) stigma masyarakat yang belum terlalu familiar atau paham dengan nama penyebutan Madrasah serta paham yang berbeda dengan Muhammadiyah sehingga munculah pemikiran bahwa jika bersekolah di sekolah Muhammadiyah maka pembelajaran yang diberikan tentu berbasis Muhammadiyah padahal tidak demikian, b) faktor pertumbuhan peserta didik memang menjadi fokus utama di sekolah tersebut sebab seperti yang sudah kita ketahui bersama banyak kasus SD - SD yang gulung tikar disebabkan faktor kekurangan peserta didik, yang tentu 
menjadi sebuah risiko di masa mendatang. Sehingga manajemen risiko yang diterapkan di MI Muhamamdiyah Kenteng ini adalah dengan melihat keadaan yang terjadi di lingkungan sekolah (internal) serta lingkungan masyarakat di sekitar sekolah (eksternal). Dilanjutkan dengan pengamatan lebih terhadap hal yang menjadi sebab munculnya sebuah risiko tersebut, kemudian dilanjutkan dengan pengambilan langkah atau tahapan selanjutannya, yakni menimbang atau mengukur sebesar apa risko tersebut bagi keberlangsungan sekolah.

\section{Pengukuran Risiko di MI Muhammadiyah Kenteng}

Pengukuran risiko ini merupakan suatu usaha yang bertujuan untuk mengetahui seberapa besar risiko yang dimungkinkan terjadi. Dalam lembaga pendidikan pun sama sebagai indikator tinggi rendahnya risiko yang akan dihadapi lembaga pendidikan tersebut, sehingga dapat memperkirakan dampak yang akan terjadi dari risiko bagi kinerja lembaga pendidikan dan sebagai pertimbangan untuk memprioritaskan risiko yang paling relevan. Sebelum dilakukanya pengukuran terhadap risiko terlebih dahulu dilakukan pengidentifikasian risiko. Yang mana bertujuan untuk menentukan relatif urgennya risiko, dan untuk menetapkan konsolidasi peralatan yang cocok untuk memanajemen risiko. (Munawwaroh, 2017)

Pengimplementasian program pendidikan di MI Muhammadiyah Kenteng dalam pengukuran risiko ini dilakukan dengan mengukur sebuah risiko yang akan terjadi melalui pengidentifikasian pada diagram pertumbuhan peserta didik, dengan melihat data tersebut dapat menerapkan tindakan apa yang perlu dilakukan untuk mengatasi risiko (kekurangan peserta didik). Karena di MI Muhammadiyah Kenteng jumlah peserta didik sangat menjadi perhatian dan hal ini dapat pengaruh pada aspek-aspek lain dalam sekolah.

Sebuah risiko jelas memberikan dampak buruk bagi yang menimpanya, untuk mengatasi hal tersebut perlu adanya sebuah strategi untuk meminimalisir risiko-risiko yang akan timbul kedepannya. Penggunaan sebuah strategi sangat tepat digunakan sebagai pengendali adanya risiko, tentu penerapan strategi ini harus selaras dengan resiko yang sedang terjadi di lapangan. Atau dengan kata lain harus mempertimbangkan faktor-faktor dari risiko tersebut. Dimana risiko internal ini sebagian besar diakibatkan oleh kalangan dalam atau anggota, yakni perbuatan manusia, manajemen yang tidak maksimal, keuangan dan lain-lain. Sebaliknya jika risiko eksternal berasal dari luar organisasi. Sehingga dalam manajmen risiko pada suatu instansi / lembaga pendidikan adalah dengan mengembangkan program pendidikan dengan baik. Karena dengan berkembangnya program pendidikan juga akan meningkatkan tercapainya mutu pendidikan.

Mutu dalam hal ini memang menjadi suatu yang sangat penting. Karena saat ini masyarakat sudah mulai merubah pola pikirnya yang dahulu hanya berfokus pada aspek kuantitas, 
saat ini sudah sampai pada aspek kualitas. Dan perlu dipahami agar terciptanya lembaga pendidikan berkualitas perlu suatu pemikiran yang menyeluruh pada manajemen atau pengelolaan terhadap elemen dalam lembaga pendidikan tersebut. Karena poin dari suatu proses pendidikan adalah pembelajaran peserta didik. Proses pembelajaran terdiri dari beberapa unsur utama yakni, tujuan pembelajaran, isi kurikulum, guru, sarana dan prasarana, dana, manajemen dan evaluasi. Dan tujuan penting dalam peningkatan mutu ialah efisiensi dan kejelasannya. (Karwati \& Priansa, 2013).

Strategi pengendalian risiko yang dilakukan MI Muhammadiyah Kenteng untuk meminimalisir risiko-risiko internal seperti :

a) Sarana dan prasarana yang kurang memadai kondisinya. Seperti yang telah kita ketahui bersama sarana dan prasarana merupakan salah satu penunjang keberhasilan Pendidikan, permasalahan sarana dan prasarana penting untuk ditangani, sebab sangat berdampak pada kelancara selama proses pembelajaran berlangsung.langkah yang diambil oleh MI Muhammdiyah Kenteng adalah dengan yakni menggunakan sebuah

b) Tenaga pendidik antar GTT dan PNS kurang seimbang. Tentu ketidakseimbangan ini akan sangat berpengaruh pada penyajian materi pada peserta didik, langkah yang sudah diterapkan di MI Muhammadiyah Kenteng adalah dengan melakukan pertemuan rutin yang didalamnya membahas mengenai pendekatan metode pembelajaran yang mudah diapliksikan dalam pembelajaran.

Sementara risiko-risiko yang berasal dari eksternal seperti :

a) Stigma masyarakat yang belum terlalu familiar atau paham dengan nama penyebutan Madrasah serta paham yang berbeda dengan Muhammadiyah sehingga munculah pemikiran bahwa jika bersekolah di sekolah Muhammadiyah maka pembelajaran yang diberikan tentu berbasis Muhammadiyah padahal tidak demikian.

b) Faktor laju pertumbuhan peserta didik di persekitaran MI Muhammadiyah Kenteng yang kurang sehingga menyebabkan jumlah peserta didik yang terdaftar saat PPDB mengalami pengurangan. Faktor utama dalam pelaksanaan pembelajaran adalah adanaya interaksi antara pendidik dengan peserta didik. Jika sebuah Lembaga pedidikan mengalami penurunan pada pserta didik akan memberikan dampak negative seperti adanya kemungkinan Lembaga sekolah tersebut gulung tikar disebabkan kurangnya peserta didik dalam Lembaga tersebut. Langkah yang sudah diterapkan MI Muhammadiyah Kenteng adalah dengan melakukan promosi sekolah lebih awal dibandingkan sekolah-sekolah lain, dengan menyebarkan pamflet baliho, metode door to door.

\section{Evaluasi Risiko di MI Muhammadiyah Kenteng}


Evaluasi merupakan tahapan yang tak kalah penting dari tahapan-tahapan sebelumnya, dapat dikatkan tahapan evaluasi ini menjadi sebuah kunci atau jalan keluar dari risiko-risiko yang dialami atau dihadapi oleh suatu lembaga. Evaluasi ini dapat dilakukan dengan berbagai jalan seperti diskusi, rapat dan sebagainya, yang mana didalamnya didiskusikan bagimana cara atau langkah yang dapat diambil dari risiko-risiko yang sudah teridentifikasi pada tahapan-tahapan sebelumnya. Dalam hasil wawancara, bahwa dalam proses pengevaluasian risiko di MI Muhammadiyah Kenteng ini dilakukan dengan langkah mengadakan pertemuan rutin yakni setiap bulan untuk membahasan terkait pelaksanan program pendidikan dan risiko atau kendala yang timbul dalam program pendidikan tersebut. Sehingga ditemukan solusi-solusi yang dapat memanajemen risko-risiko tersebut, jadi dalam hal ini dapat dimengerti bahwa suatu proses mananjeman risiko ini harus selalu dilakukan secara berkelanjutan dan terus dikaji bersama.

\section{KESIMPULAN DAN SARAN}

Dari hasil penelitian yang dilakukan dapat disimpulkan bahwa manajemen risiko merupakan sebuah proses mengidentifikasi, menganalisis, menilai, mengendalikan, dan menghindari, meminimalisir, atau menghapuskan risiko yang tidak tervalidasi atau diterima. Hadirnya manajemen risiko ini memungkinkan sekolah untuk mengantisipasi, mengelola segala risiko yang dikhawatirkan terjadi atau sedang terjadi. Selain itu manajemen risiko menjadikan risiko-risiko tersebut sebagai suatu rujukan untuk perbaikan dan pengembangan sekolah sehingga risiko-risiko tersebut tidak terulang di kemudian hari.

Berdasarkan jenis risiko kemunculannya pada pelaksanaan program pendidikan, risiko dibedakan menjadi dua yaitu risiko internal dan risiko eksternal. Risiko internal ini berkaitan dengan pemenuhan Standar Nasional Pendidikan yang terdiri atas risiko operasional, risiko SDM, risiko kerugian, risiko waktu. Kemudian risiko eksternal berkaitan dengan risiko reputasi cara pandang orang tentang sekolah tersebut. Di MI Muhammadiyah Kenteng manajeman risiko sudah dapat dikatakan terlaksana dengan baik, dimana telah terlaksana beberapa tahapan dalam manajmen risiko tersebut. Sehingga tahapan-tahapan dalam manajemen risiko ini harus dijalankan secara berkelanjutan, agar suatu lembaga pendidikan dapat berjalan dengan baik dan risiko yang akan terorganisir dengan baik.

\section{DAFTAR PUSTAKA}

E.Mulyasa. (2012). Manajemen dan Kepemimpinan Kepala Sekolah. Jakarta: Bumi Aksara.

Karwati, \& Priansa, D. J. (2013). Kinerja dan Profesionalisme Kepala Sekolah Membangun Sekolah yang Bermutu. Bandung: Alfabeta. 
Munawwaroh, Z. (2017). Analisis Manajemen Risiko Pada Pelaksanaan Program. Jurnal Administrasi Pendidikan Vol.24 No.2, 74.

Syam, J. (2016). Pendidikan Berbasis Islam yang Memandirikan dan Mendewasakan. EduTech: Jurnal Ilmu Pendidikan dan Ilmu Sosial, 2(2).

Sidiq, U., \& Choiri, M. M. ( 2019). Metode Penelitian Kualitatif Di Bidang Pendidikan . Ponorogo: CV. Nata Karya.

Subagyo, A., Simanjutak, R., \& Irianto, A. (2020). Dasar-Dasar Manajemen Risiko. Jakarta: Mitra Wacana Media.

Winoto, S. (2020). Dasar-Dasar Manajemen Pendidikan. Yogyakarta: CV. Bildung Nusantara. 